\title{
Quaternary climate change in south-eastern Arabia
}

Frank Preusser ${ }^{1}$ and Dirk Radies ${ }^{2}$

${ }^{1}$ Institute of Geological Sciences, University of Bern, Switzerland; preusser@geo.unibe.ch

${ }^{2}$ Geological Institute, RWTH Aachen University, Germany; email; dradies@web.de

The present day climate over the south-eastern Arabian Peninsula is characterized by pronounced arid conditions. The aridity is due to the presence of the Intertropical Convergence Zone (ITCZ) over the southernmost part of the peninsula during summer, which prevents the movement of humid air masses north (Fig. 1a). Precipitation, resulting from moisture transported by southwesterly winds across the Indian Ocean and towards the Tibetan Plateau (Summer Monsoon), is only recognized as coastal fog and seasonal rainfall in the southern part of Oman (Dohfar), without affecting other parts of the region. During the winter, when the ITCZ is positioned south of the equator, a persistent high-pressure cell, accompanied by weak wind and very low precipitation, establishes itself over central Oman (Fig. 1b).

\section{Increased precipitation in the past}

Past humid periods are evidenced by the presence of ancient lake deposits in the south-western Rub' al Khali of Saudi Arabia and Yemen (McClure, 1976; Lezine et al., 1998) and, more recently, in the Wahiba Sand Sea of eastern Oman (Radies et al., 2005). These deposits, based on radiocarbon and luminescence dating, are attributed to a period of humid conditions during the early to middle Holocene (ca. 10,000 to 5000 yr ago). Faunal assemblages from the Wahiba Sand Sea reveal that these lakes were permanent with a developed shore margin environment. The availability of water was sufficient to sustain a vegetation cover in the wider surroundings of the lakes, attracting large herbivores, as indicated by the presence of dung beetle balls and cocoons. Neolithic arrowheads, found in association with the former lake deposits, indicate the presence of human hunter communities in the region. If all other climatic variables are kept constant, an increase in an-

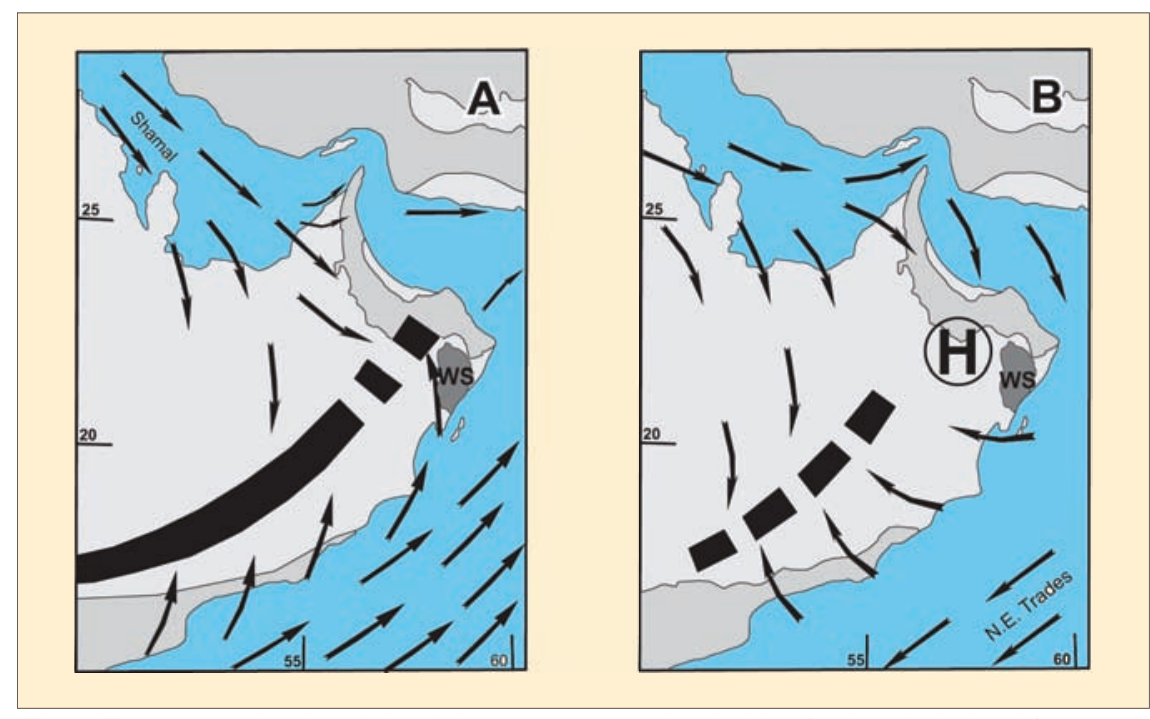

Fig. 1: The present low-level circulation pattern over the Arabian Peninsula during (a) summer and (b) winter, with the approx. summer position of the ITCZ. WS marks the position of the Wahiba Sand Sea. The dashed line in (b) represents the temporally occurring local convergence and $\mathrm{H}$ marks the approx. position of the winter high-pressure cell (modified after Preusser et al., 2002).

nual precipitation from the present value of less than $100 \mathrm{~mm}$ to about $250 \mathrm{~mm}$ would be necessary to sustain such environmental conditions (Radies et al., 2005).

Evidence for the Early Holocene wet period is also recorded in the growth of speleothems. $\delta^{18} \mathrm{O}$ records of the speleothems indicate a rise in precipitation starting at about 10,000 yr ago (Burns et al., 1998, 2001; Fleitmann et al., 2003 a, b). The increase in precipitation is interpreted to result from a northward shift of the ITCZ that forced moisture from the Indian Ocean over the Arabian Peninsula. Speleothems from southern Arabia give evidence for further humid periods in the past, dated by Th/U to 320,000 $300,000,200,000-180,000,135,000$ 120,000 , and $82,000-78,000 \mathrm{yr}$ ago (Burns et al., 2001) (Fig. 2). All these periods represent times of higher summer insolation on the northern hemisphere and correspond with interglacial conditions in the middle to high latitudes (apart from the period 82,000-78,000 yr ago which corresponds to pronounced interstadial conditions). This indicates that the Arabian Peninsula experienced periods of higher mean annual precipitation in the past due to a strengthening of monsoon circulation associated with a northward shift of the ITCZ.

Changes in moisture availability also had an impact on the sedimentary architecture of the Wahiba Sand Sea. Between 170,000-140,000 and $120,000-100,000$ yr ago, periodic changes in moisture availability led to the establishment of a dominantly groundwater-controlled eolian architecture characterized by numerous paleosol horizons intercalated with dune deposits. This implies that these periods were probably characterized by a high variability of mean annual precipitation on a millennial scale. On the other hand, younger eolian deposits formed between 35,000-8,000 yr ago show no evidence of paleosol development, which implies that this period reflects more pronounced arid conditions on a scale of some ten thousand years (Radies et al., 2004; Preusser et al., 2005).

\section{Atmospheric circulation during glacial periods}

During times of insolation minima in the northern hemisphere, monsoon precipitation was weaker than today with the resultant more intense arid conditions. These periods 


\section{Science Highlights}

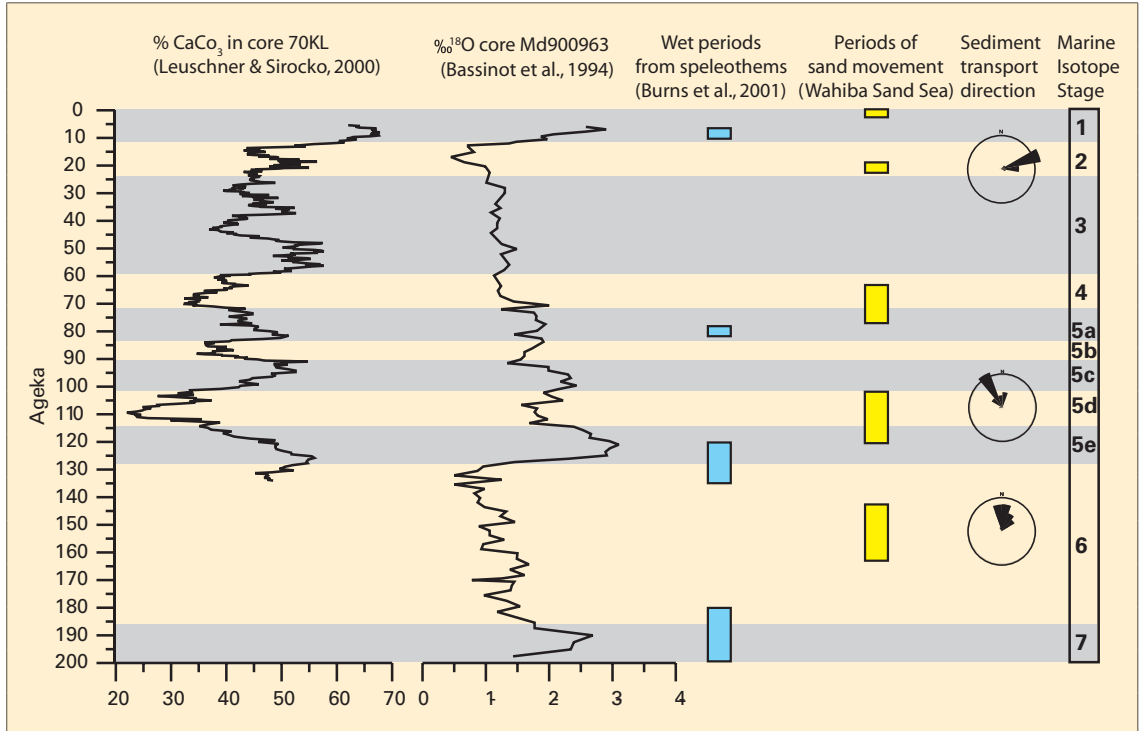

Fig. 2: Comparison of $\mathrm{CaCO}_{3}$ content in core $70 \mathrm{KL}$ (as an inverse measure of dust input), and the oxygen isotope record from core Md900963 from the Maldives area las a measure of global ice volume and global sea level), with the timing of eolian deposition in the Wahiba Sand Sea. The individual duration of these periods was calculated from the standard deviation of weighted mean luminescence ages. Rose-diagrams show the distribution of sand transport vectors in the Wahiba Sand Sea from outcrop studies. Additionally shown are periods attributed to higher than present precipitation, as deduced from speleothem growth (modified after Preusser et al., 2002).

of pronounced aridity are reflected in the increase of terrestrial dust in marine sediments of the Arabian Sea (Sirocko et al., 1991, 1993; Leuschner and Sirocko, 2000, 2003). The increase of eolian input has been explained by northwesterly winds transporting dust from the north towards the ITCZ. This implies that the ITCZ established a summer position further south than today and was located over the Arabian Sea (Sirocko et al., 1991). While this scenario appears almost conclusive, it has been questioned by recent evidence from the Wahiba Sand Sea of eastern Oman (Fig. 1).

The Wahiba Sand Sea is characterized by widespread eolian sand deposits that partially form mega-dune ridges up to $70 \mathrm{~m}$ high. The sand deposits comprise large amounts of bioclasts, such as shell debris, etc., implying a continental shelf source that was exposed during periods of low global sea level. Southerly winds transported this sand from the shelf onto the continent. Interestingly, the northern margin of the area, covered by large amounts of eolian sands, coincides approx. with the southern edge of the present position of the ITCZ during summer. At this position, wind velocity dissipates, preventing any further substantial transport of sand grains towards the north. Luminescence dating of several outcrops, together with two sediment cores from the northern Wahiba Sand Sea, confirms the correlation of sand accumulation with periods characterized by prominent decreases of global sea level (Fig. 2). The dating results indicate periods of pronounced eolian deposition in the northern part of the Wahiba Sand Sea between 160,000$140,000,120,000-100,000,78,000-$ 64,000 , and 22,000-18,000 yr ago (Preusser et al., 2002). Moreover, dip directions of dune fore-sets indicate an exclusively northbound transport of sand.

This evidence from continental environments contradicts the assumption by Sirocko et al. (1991, 1993) that the ITCZ established a summer position south of the Arabian Peninsula during glacial times. In that case, the area of the Wahiba Sand Sea would have been situated north of the ITCZ and dominated by winds with a southeasterly direction, which would have inhibited the development of a sand sea with strong bioclastic input. Sirocko et al. (1991) concluded from the mineralogical composition that the dust probably derived from the Persian Gulf area. The rather shallow Persian Gulf was a dry basin during most of the Quaternary and an ideal source area for the dust found in Arabian Sea sediments. The most prominent input of dust in the Arabian Sea at around 110,000 yr ago concurs with the sudden drop of sea level immediately following the Last Interglacial (Fig. 2). This time is also characterized as the most prominent period of deposition in the Wahiba Sand Sea. While Sirocko et al. (1991) favored a lowlevel atmospheric transport of dust towards the south, Preusser et al. (2002) suggest that the dust was first transferred into the higher atmosphere. The persistent NW-SE oriented jet stream present over the Arabian Peninsula could have transported the dust into higher atmospheric layers, across the ITCZ and released the material into the Arabian Sea. Alternatively, dust input into the Arabian Sea could have been derived from even more northerly sources, such as the interior deserts of Iran and Afghanistan, during winter months. A recent dust storm event in December 2003 covered the Arabian Sea and southeastern Arabia for several days. Both scenarios reconcile evidence from marine and continental environments but imply that the ITCZ had a similar summer position over the eastern Arabian Peninsula during glacial times as it has today.

\section{REFERENCES}

Burns, S.J., Fleitmann, D., Matter, A., Neff, U. and Mangini, A., 2001: Speleothem evidence from Oman for continental pluvial events during interglacial periods. Geology, 29, 623-626.

Preusser, F., Radies, D. and Matter, A., 2002: A 160,000-Year record of dune development and atmospheric circulation in Southern Arabia. Science, 296: 2018-2020

Radies, D., Preusser, F., Matter, A. and Mange, M., 2004: Eustatic and climatic controls on the development of the Wahiba Sand Sea, Sultanate of Oman. Sedimentology, 51: 1359-1385.

Radies, D., Hasiotis, S.T, Preusser, F., Neubert, E. and Matter, A., 2005: Paleoclimatic significance of Early Holocene faunal assemblages in wet interdune deposits of the Wahiba Sand Sea, Sultanate of Oman. Journal of Arid Environments, 62, 109-125.

Sirocko, F., Sarnthein, M., Lange, H. and Erlenkeuser, H., 1991: Atmospheric summer circulation and coastal upwelling in the Arabian Sea during the Holocene and the Last Glaciation. Quaternary Research, 36: 72-93.

For full references please consult: www.pages-igbp.org/products/newsletters/ref2006_1.html 